Winter 2008

\title{
The WTO and Domestic Political Disquiet: has Legalization of the Global Trade Regime Gone Too Far?
}

James R. Cohee

Indiana University School of Law

Follow this and additional works at: https://www.repository.law.indiana.edu/ijgls

Part of the International Law Commons, and the International Trade Law Commons

\section{Recommended Citation}

Cohee, James R. (2008) "The WTO and Domestic Political Disquiet: has Legalization of the Global Trade Regime Gone Too Far?," Indiana Journal of Global Legal Studies: Vol. 15 : Iss. 1 , Article 14.

Available at: https://www.repository.law.indiana.edu/ijgls/vol15/iss1/14

This Note is brought to you for free and open access by the Law School Journals at Digital Repository @ Maurer Law. It has been accepted for inclusion in Indiana Journal of Global Legal Studies by an authorized editor of Digital Repository @ Maurer Law. For more information, please contact rvaughan@indiana.edu.

\section{$\Psi$}

JEROME HALL LAW LIBRARY

INDIANA UNIVERSITY

Maurer School of Law
Bloomington 


\title{
The WTO and Domestic Political Disquiet: Has Legalization of the Global Trade Regime Gone Too Far?
}

\author{
JAMES R. COHEE*
}

Abstract

The recent "legalization" of the global trade regime (the WTO) has inspired enormous amounts of research and literature. Fewer commentators, however, have examined WTO legalization from the perspective of domestic interest groups. I add to this growing subfield of literature by arguing that the WTO has not exceeded its boundary for domestic political acceptance, nor will it likely do so in the near future. In one respect- "judicial activism"-legalization does, however, present a threat to domestic political support. Still, drawing from historical lessons, I argue that the WTO as an institution will face irrelevance only if both protectionists and multilateralists conclude that the institution no longer represents their interests.

\section{INTRODUCTION}

Much has been written about the increased legalization of the World Trade Organization (WTO), a shift described, in the most general of terms, as one from an "ethos of diplomats" to the "rule of lawyers." Commentators have weighed in on the benefits and drawbacks of legalization, stressing that, while a strong rule of

* J.D., 2008, Indiana University School of Law-Bloomington, MSc., London School of Economics and Political Science, 2005, B.A., Indiana University-Bloomington, 2001. Many thanks to Professor David Fidler, Professor Hannah Buxbaum, and the Editorial Board and Associates of the Indiana Journal of Global Legal Studies; all errors contained in this note, however, remain solely my responsibility.

1. J.H.H. Weiler, The Rule of Lawyers and the Ethos of Diplomats: Reflections on the Internal and External Legitimacy of WTO Dispute Settlement, 13 Am. Rev. INT'L Arb. 177, 177 (2002).

Indiana Journal of Global Legal Studies Vol. $15 \# 1$ (Winter 2008)

CIndiana University School of Law 
law ensures that nations abide by their commitments to the WTO, ${ }^{2}$ legalization has too often resulted in undemocratic developments, with judges and lawyers filling gaps left (sometimes intentionally) by negotiators. ${ }^{3}$ This debate has meaningful implications for the future of the WTO as a global institution, for as Miles Kahler writes, "The significance of legalization lies neither in its inevitability nor its desirability in every international context. It remains but one institutional choice... that a growing number of actors have grasped to advance their goals." ${ }^{, 4}$

Nor is a legalized WTO by any means permanent-regime choices can be reversed, according to Kahler, if there is a changed "calculus of actors," and indeed, a growing subfield of the WTO legalization literature examines the calculus of domestic political actors who initially supported (or at least acquiesced to) legalization of the international trade regime. ${ }^{6}$ When the WTO Agreement was signed in 1994, a careful balance was struck between liberalization and protection for domestic producers. Negotiators played the "two-level" game ${ }^{7}$ and consulted with domestic interest groups over the course of the Uruguay Round. An agreement was reached only after states' domestic win-sets were satisfied, most notably in the United States. ${ }^{8}$ The principle question at hand, therefore, is whether the balance has tipped, and the legalized trade regime has moved out of its domestic political boundary, threatening to undermine overall support for the regime.

Instead of undertaking the insurmountable task of examining the domestic politics of all, or even most WTO members, I have instead chosen to use the United States as a case study. There are several reasons for this choice: first, the United States is the largest single country economy in the world and one of the most important members of the WTO. Indeed, it would be difficult to conceive of a global trade regime without the United States, and any major institutional reform (of the Dispute Settlement Body (DSB), for example) would likely be a result of U.S. initia-

2. See, e.g., John H. Jackson, Dispute Settlement and the WTO: Emerging Problems, 1 J. INT'L Econ. L. 329, 340 (1998).

3. See, e.g., Marco C. E. J. Bronckers, Better Rules for a New Millennium: A Warning Against Undemocratic Developments in the WTO, 2 J. INT'L EcoN. L. 547, 554-56 (1999).

4. Miles Kahler, Conclusion: The Causes and Consequences of Legalization, 54 INT'L OrG. 661, $683(2000)$.

5. Id. at 680 .

6. See, e.g., Judith Goldstein \& Lisa L. Martin, Legalization, Trade Liberalization, and Domestic Politics: A Cautionary Note, 54 INT'L ORG. 603 (2000); Richard H. Steinberg, Judicial Lawmaking at the WTO: Discursive, Constitutional, and Political Constraints, 98 A M. J. INr'L L. 247, 263-72 (2004).

7. Robert D. Putnam, Diplomacy and Domestic Politics: The Logic of Two-Level Games, 42 INT'L Org. 427, 434 (1988).

8. Goldstein \& Martin, supra note 6, at 610. 
tive or at least consent. ${ }^{9}$ Second, it has also been one of the WTO's loudest critics of late. ${ }^{10}$ Third, U.S. domestic political dynamics are especially vital to the formation of trade policy: "Domestic political factors define [U.S.] foreign economic policy and [mold] the government's scope for [maneuver] to a greater degree than in virtually any other advanced country."11 Finally, history shows that the United States was one of the original and most ardent supporters of legalization during the Uruguay Round. The United States pushed for a stronger dispute settlement mechanism to stop other nations from alleged cheating on their trade commitments. It was the European Union and others that were initially reluctant to commit themselves to a binding dispute settlement mechanism, and only after the United States offered to relinquish its Section 301 measure was a consensus built. ${ }^{2}$ For these reasonseconomic importance, WTO institutional importance, recent criticism, domestic political dynamics, and initial support of legalization-the United States is an important case study.

This is not to say, of course, that other WTO Members wholeheartedly support the DSB. The other major WTO power, the European Union, has had difficulties with the DSB (The European Communities Bananas Case ${ }^{13}$ and European Communities Beef Hormones case ${ }^{14}$ are prime examples). Still, overall, the EU has had at most a successful experience with the system, and at least not near the contentious relationship of the United States..$^{15}$ Moreover, despite the EU's difficulties, accusations of a WTO assault on domestic sovereignty are notably absent, which is not the

9. See, e.g., Steinberg, supra note 6, at 265 ("The European Communities and the United States have dominated GATT/WTO decision making since the 1960s.").

10. See, for example, the extremely controversial and only recently-repealed Continued Dumping and Subsidy Offset Act (Byrd Amendment), 19 U.S.C. $\$ 1675$ c (1999 \& Supp. 2002) (repealed 2006).

11. Gautam Sen, The United States and the GATT/WTO System, in U.S. Hegemony and InTERnational Organizations: The United States and Multilateral Institutions 115, 119-20 (Rosemary Foot et al. eds., 2003).

12. Whether the Congress actually was offering the end of Section 301 as a direct quid pro quo for an enhanced dispute settlement mechanism is still debated. However, once the idea was floated, the Europeans and others jumped on the chance, forcing the United States to agree to the measure, lest it be viewed as backing down from the commitment to legalization that it had so vehemently pushed until that point. A good history of the legalization negotiations at the Uruguay Round can be found in G. Richard Shell, Trade Legalism and International Relations Theory: An Analysis of the World Trade Organization, 44 Duke L.J. 829, 842-53 (1995).

13. WTO Panel Report, European Communities-Regime for the Importation, Sale and Distribution of Bananas WT/DS27/R (May 22, 1997).

14. WTO Appellate Body Report, EC Measures Concerning Meat and Meat Products (Hormones) WT/DS48/R (Jan. 16, 1998).

15. Steinberg, supra note 6 , at $271-73$. 
case among U.S. commentators. ${ }^{16}$ Middle-sized countries such as Korea have also had a mixed experience with the DSB: "According to the statistics until the end of 2002, no other WTO Member country, except for Argentina, has been so disproportionately challenged by the dispute settlement system. And yet, Korea has been fully cooperative in implementing the DSB recommendations. ${ }^{\prime \prime 7}$ Finally, for developing countries, utilization of the DSB is not frequent enough to obtain an accurate judgment: "African countries have largely been absent as players at the WTO dispute settlement system in its first decade."18 Therefore, by choosing to use the United States as a case study, I do not mean to suggest that challenges to the WTO DSB's legitimacy will not emanate from other origins. I do mean to suggest, however, that, because of the reasons delineated above, studying the United States gives global political science and legal scholars the best lens through which to judge the DSB's legitimacy within domestic political discourse.

The term "domestic political group" needs to be clarified at the outset as well. By this I am referring to groups with a direct economic interest in trade-importcompetitors and export groups. To be sure, environmental, labor, and other issue non-governmental organizations (NGOs) are far from irrelevant and have indeed been some of the WTO's loudest critics. But as Marcus Noland writes, U.S. trade policy is determined by a narrow group of special interests. ${ }^{19}$ "Despite the rise of the 'new issues', the old issue of protection remains central to the U.S. trade policy agenda." ${ }^{20}$

It is the principal contention of this paper that WTO legalization has not exceeded its domestic political boundaries in the United States, nor in many ways is it likely to do so in the future. By examining the various aspects of WTO rules, we shall see that there is more flexibility in, and less animosity for, the legalized regime than purported. It should be noted here that this paper does not take a position in the debate over whether legalization is a welcome or unwelcome development; the aim of this piece is to examine WTO legalization from a descriptive, not normative, perspective.

16. See, e.g., Paul B. Stephan, International Governance and American Democracy, 1 CHI. J. INT'L L. 237, 237 (2000).

17. Dukgeun Ahn, Korea in the GATT/WTO Dispute Settlement System: Legal Battle for Economic Development, 6 J. INT'L Econ. L. 597, 631 (2003).

18. Victor Mosoti, Africa in the First Decade of WTO Dispute Settlement, 9 J. INT'L Econ. L. 427, 427 (2006).

19. Marcus Noland, The New protectionists: The Privatization of US Trade Policy 9 (1999).

20. Id. at 12. 
The paper is organized in the following manner: the next section discusses the framework used to examine legalization in international organizations. That framework is then applied to various aspects of the international trade regime that were legalized with the signing of the Uruguay Round Agreement (URA). The subsequent three sections examine each aspect of legalization as applied to the WTO and analyze whether a domestic political boundary has been crossed. I then offer some concluding thoughts.

\section{Defining "Legalization"}

Several changes from the General Agreement on Tariffs and Trade (GATT) 1947 to GATT 1994 have been cited in the academic literature as indications of a legalization of the global trade regime. Examples include tightening safeguards, delegating authority to the DSB, "judicial activism," increased precision of the trade rules, and automatic panel formation and ruling. ${ }^{21}$ Each will be examined below, but in the interest of streamlined analysis, I have grouped them within a model developed in the international relations literature. This model, developed by Kenneth Abbott, et. al, is "intended to frame"22 and defines legalization into three workable categories: "obligation," "precision," and "delegation." Indeed, the authors write of their own definition: "Defining legalization in terms of obligation, precision, and delegation provides us with identifiable dimensions of variation whose effects on international behavior can be empirically explored."23

Obligation "means that states or other actors are bound by a rule or commitment or by a set of rules or commitments." ${ }^{44}$ Precision means that a "rule specifies clearly and unambiguously what is expected of a state or other actor (in terms of both the intended objective and the means of achieving it) in a particular set of circumstances." ${ }^{25}$ Finally, delegation "means that third parties have been granted authority to implement, interpret, and apply the rules; to resolve disputes; and (pos-

21. See, e.g., William J. Davey, Has the WTO Dispute Settlement System Exceeded Its Authority? A Consideration of Deference Shown by the System to Member Government Decisions and Its Use of Issue-Avoidance Techniques, 4 J. Int'L Econ. LAw 79 (2001); Goldstein \& Martin, supra note 6, at 604; Jackson, supra note 2 . Along with the above aspects of legalization should also be developments such as the agreement on Trade-Related Aspects of Intellectual Property (TRIPs), the General Agreement on Trade in Services (GATS), and others.

22. Kenneth W. Abbott et al., The Concept of Legalization, 54 INT'L ORG. 401, 403 (2000).

23. Id.

24. Id. at 401 .

25. Id. at 412 . 
sibly) to make further rules." ${ }^{\text {"6 }}$ These third parties, moreover, "are authorized to interpret rules and apply them to particular facts (and therefore in effect make new rules, at least interstitially) under established doctrines of international law. ${ }^{27}$

\section{The Concepts of Legalization Applied to the WTO}

In this section, the three categories of legalization will be applied to numerous aspects of the WTO that have been cited in the literature as legalized. Indeed, clarity is needed concerning how these aspects should be appropriately categorized because confusion exists, even among experts. Kahler writes that Judith Goldstein and Lisa Martin study the "precision" and "delegation" of the WTO in their 2000 article. ${ }^{28}$ Instead, what is clear from Goldstein and Martin's study is that their primary aim is to examine the "precision" and "obligation" of the WTO as defined in the Abbott, et al. piece. "Delegation" is covered, to be sure, but only by extension. ${ }^{29}$ Therefore, each category of Abbott, et al.'s model is addressed below, with explanations as to why aspects of legalization are grouped in respective categories.

\section{A. Obligation}

Within the context of this paper, there are two aspects of WTO legalization that constitute increased obligation of the states: the tightening of safeguards and the automatic adoption of DSB panels and rulings. ${ }^{30}$ Safeguards are pressure valves in the global trade regime which allow a country to legally suspend trade agreements, if, "as a result of unforeseen developments," a past tariff concession causes "serious injury" to domestic producers. ${ }^{31}$ GATT 1994 tightened them from their 1947 version in the following ways: a sunset clause was set on safeguardsgenerally, they could only last four years, but in some cases it could be eight-and

26. Id. at 401.

27. Id. at 415 .

28. Kahler, supra note 4 , at 665.

29. Goldstein \& Martin, supra note 6.

30. I have chosen to focus my analysis on the traditional aspects of trade within the WTO, meaning traditional rules that affect trade in goods. It is important to note, however, that I acknowledge new Member obligations in areas such as the agreement on TRIPs, GATS, or the Agreement on Sanitary and Phytosanitary Measures, just to name a few. These are certainly important developments in the WTO, and play an important role in shaping its dynamics. In the interest of brevity and streamlined analysis, however, some legalization aspects must be excluded.

31. General Agreement on Tariffs and Trade, Apr. 15, 1994, Annex 1A, Multilateral Agreement on Trade in Goods, 33 I.L.M. 1154 (1994) at art. XIX. 
existing safeguards under GATT 1947 at the time of signing the URA had to be phased out within eight years, becoming more liberal year by year. ${ }^{32}$ The definition of what constitutes "serious injury" was also tightened, and a provision was included allowing the victim of a safeguard to withdraw equal concessions, though this could not be done in the first three years of a safeguard's life. ${ }^{33}$ Finally, voluntary export restraints (VERs) and Orderly Marketing Arrangements (OMAs) were outlawed. ${ }^{34}$

The second aspect of WTO obligation is the automatic panel formation and rulings. Under GATT 1947, dispute resolution had a palpable conciliatory and diplomatic underpinning. If a state allegedly violated the terms of the Agreement, then the injured party could protest and request a panel. However, because the GATT 1947 worked on a consensus-vote approach, a single state, including the accused party, could block the creation of a panel. Moreover, even if the accused state initially acquiesced to the panel creation, it could block adoption of its result if it did not agree with the outcome. ${ }^{35}$ Now, any state that calls for a panel has it granted (if the dispute is not worked out in consultation) and adoption of the panel's ruling can be blocked only if there is a consensus of WTO Members, which means the winner of the case must agree to overturn its victory-essentially, the opposite of what existed under GATT 1947.36

At first glance, one might be tempted to classify automatic DSB panel formation as "delegation." This is misleading. Consider the following hypothetical scenario: suppose a state receives a negative ruling from the DSB and disagrees with the legal reasoning used to decide the outcome. The state will likely be upset for two reasons: it was unfairly judged, and it is obliged to comply with the ruling. These are two separate issues. Suppose this state is asked for suggestions on how to reform the WTO. It could very well call for less delegation (because it wants more control over how cases are decided), but has no problem with rulings being binding. In fact, the United States has done just that-it continues to stress the importance of the "rule of law" (and remember, it led the charge for a more binding system), but has questioned the legal reasoning used by the DSB to reach de-

32. Id.

33. Id.

34. Id.

35. Rachel Brewster, Rule-Based Dispute Resolution in International Trade Law, 92 V. L. Rev. $251,254-55$ (2006).

36. Understanding on Rules and Procedures Governing the Settlement of Disputes, Apr. 15 1994, Marrakesh Agreement Establishing the World Trade Organization, Annex 2, Legal Instruments-Results of the Uruguay Round, 33 I.L.M. 1125 (1994) [hereinafter DSU]. 
cisions. ${ }^{37}$ Therefore, for the purposes of this paper, the fact that panel formation and rulings are binding is considered an obligation.

\section{B. Precision}

Abbott, et al. write that "precise sets of rules are often, though by no means always, highly elaborated or dense, detailing conditions of application, spelling out required or proscribed behavior in numerous situations, and so on." ${ }^{38}$ The WTO certainly fits this description-the URA, including tariff schedules, is more than 26,000 pages long. ${ }^{39}$ But the argument about rule precision is more subtle-it refers to the clarity in the steps followed in the event of a breach. A situation where all parties have knowledge of expectations and procedures, it is argued, will elicit more interest group awareness, more transparency, and as a result, more opposition to the trade regime ${ }^{40}$ Increasing precision, therefore, refers to the fact that there are more rules, and more specifically proscribed behavior, but not the fact that the rules are more binding.

\section{Delegation}

Delegation within the context of the WTO means the authority Members delegated to the DSB to resolve trade disputes. Judging by the number of cases brought by states as compared to the GATT 1947 dispute resolution system (there has been a four-fold increase in cases initiated ${ }^{41}$ ), the "crown jewel" of the URA seems to be a success. The seemingly controversial element of delegation, however, rests in the manner in which the DSB has ruled on cases, not the number. The Panels and the Appellate Body have been accused of "judicial activism" by the United States and others by interpreting in or out rights and responsibilities not contained within the WTO text. ${ }^{42}$ These Members claim that judicial activ-

37. See, e.g., Executive Branch Strategy Regarding WTO Dispute Settlement Panels and the Appellate Body, Report to Congress Transmitted by the Secretary of Commerce 8-10 (Dec. 30, 2002) [hereinafter RePORT to Congress] available at http://www.ita.doc.gov/Final Dec31 ReportCorrected.pdf.

38. Abbott et al., supra note 22, at 413.

39. The text of the URA is available at http://www.wto.org/english/docs_e/legal_e/legal_e .htm (last visited May 12, 2008).

40. Goldstein \& Martin, supra note 6, at 604.

41. Jackson, supra note 2, at 339.

42. See generally J. Patrick Kelly, Judicial Activism at the World Trade Organization: Developing Principles of Self-Restraint, 22 Nw. J. INT'L. L. \& Bus. 353 (2002) (stating that the "linkage of 
ism was not the intent of Uruguay Round negotiators, and in particular, the United States is upset about these "undemocratic developments" trade remedies and safeguards. Examples of alleged judicial activism include: US-Hot-Rolled Steel from Japan, U.S.-Offset Act ("Byrd Amendment"), and Argentina-Footwear ${ }^{45}$ where in all, the panels and/or Appellate Body allegedly either ignored specific provisions of WTO text, or read the text so closely as to redefine words. ${ }^{46}$

\section{Is Increased Obligation in Danger of Undermining Domestic Political Support for the WTO?}

The two aspects of obligation-reduced access to safeguards and automatic panel formation and ruling adoption-will be discussed in this section. For both aspects, the potential threat to domestic political support will be assessed, and then refuted.

\section{A. Safeguards}

Safeguards are one example of the "embedded liberalism"47 in the post-World War II international economic order because they allow states that need to temporarily breach trade commitments in times of economic crisis to protect domestic producers. They are a safety valve, and if states do not have access to them, states may be reluctant to sign new agreements ${ }^{48}$ and domestic interest group support for continued WTO involvement may wane. Additionally, safeguards play an important role in the United States by buffering Members of Congress from direct contact by special interests. If a Senator's constituents are demanding protection,

social regulatory policies with trade might occur by judicial activism at the Appellate Body").

43. See generally Bronckers, supra note 3, at 547 (stating that inadequate rules have lead to undemocratic developments and a weakening of the organization).

44. See section III.B., infra.

45. See section V., infra.

46. Richard O. Cunningham \& Tony H. Cribb, Dispute Settlement Through the Lens of "Free Flow of Trade," 6 J. INT'L Econ Law 155, 158 (2003) ("Thus, a frustration for the United States (and other nations whose AD and CVD decisions are challenged) is that the Panelists' textual analysis is so detailed that it often leads to redefinition of words, or to the reading into the text limitations that are not there in black and white.").

47. John Gerard Ruggie, International Regimes, Transactions, and Change: Embedded Liberalism in the Postwar Economic Order, 36 Int'L Org. 379 (1982).

48. Goldstein \& Martin, supra note 6 , at 622. 
he or she can pass the claim off to the International Trade Commission (ITC) which administers safeguards. ${ }^{49}$ But if this buffer becomes ineffective, then domestic groups will turn back to their Members of Congress for help, which could lead, as it has in the past, to calls for increased protection.

The GATT 1994 limits on safeguards, however, do not pose an immediate threat to U.S. domestic political support of the WTO. Safeguards are, above all, still legal, even if their practical use is limited: "[t]he inclusion of Article XIX itself was of more symbolic than practical importance." ${ }^{.50}$ Instead, the United States is more likely to turn to antidumping (AD) and countervailing duty (CVD) laws to deliver protection to domestic groups (although, as explained later, these are somewhat more limited as well). Additionally, despite their illegality, the United States still uses VERs and other non-tariff barriers to protect: "examples of [U.S.] unilateral action range from non-tariff barriers like VERs, supposedly abandoned under the WTO, to the notorious structural impediments initiative vis-à-vis Japan and quantitative import targets. ${ }^{.11}$ This paper, therefore, concurs with Guatam Sen that "The U.S . . exercises wide latitude of independent discretion to determine and remedy transgression and injury to U.S. domestic interests." ${ }^{22}$

\section{B. Automatic Panel Formation and Binding DSB Rulings}

The perceived threat that automatic panel and ruling adoption poses is that states cannot breach their obligations when domestic interest groups demand it, contributing to a loss of domestic political support over time. However, panel formation may not be as automatic as it might seem, and compliance with rulings has hardly been assured. Therefore, there is still a considerable amount of flexibility in the WTO judicial system.

For example, powerful states can exert political influence during the consultation period. Before a dispute goes before a panel, the parties are given 60 days to consult with each other and possibly settle out of court. ${ }^{53}$ It is during this closeddoor, power-politics bargaining session "in the shadow of the law" ${ }^{54}$ that panel formation loses some of its automatic nature because powerful states can induce

49. See Sen, supra note 11 , at 126.

50. Id. at 127.

51. Id. at 128.

52. Id.

53. DSU, supra note 36.

54. Richard H. Steinberg, In the Shadow of Law or Power? Consensus-Based Bargaining and Outcomes in the GATT/WTO, 56 INT'L. ORG. 339 (2002). 
settlements by overwhelming developing states with fewer legal resources..$^{55} \mathrm{Fi}$ nally, the empirical evidence supports such notions: "[o]nly about 45 percent of all GATT/WTO disputes ... have reached the stage of establishment of panels; and little more than a third have lasted until a panel report was issued." ${ }^{.56}$

The proliferation of lawyers specializing in WTO law has also made panel formation less automatic for the United States. Private legal services are expensive, and with few legal experts in house, the sheer cost to a developing country of bringing a case (even to consultation) is a deterrent. Therefore, most experts conclude that Members do not bring as many cases as they could; they only bring the cases they believe have a strong chance to win. A state may also avoid filing cases because it "may not want to draw attention to the dubious legality of policies it, too, employs." 57 Ultimately, evidence points to the fact that developing countries "are one-third less likely to file complaints against developed states under the WTO than they were under the post-1989 GATT regime." 58 Therefore, even though the power politics of the GATT may be gone, it has been replaced by the power legalism of the WTO.

The lack of compliance enforcement also affords Members a significant amount of flexibility. As explained by Judith Bello: "Like the GATT rules that preceded them, the WTO rules are simply not 'binding' in the traditional sense. . . The WTO has no jailhouse, no bail bondsmen, no blue helmets, no truncheons or tear gas." ${ }^{\text {99 }}$ Instead, the WTO is essentially a confederation of states that relies upon "voluntary compliance." 60

If a Member is found in breach, it is expected to remove the "illegal" behavior immediately, but if removal is impossible or impractical, the losing Member is granted a "reasonable period of time" wt within which to comply. In practice, this period has ranged from three to fifteen months-the exact amount to be determined by the parties through agreement or binding arbitration..$^{62}$ If compliance is not achieved within this period of time, consultations between the parties begin before the time

55. Marc L. Busch \& Eric Reinhardt, Testing International Trade Law: Empirical Studies of GATT/ WTO Dispute Settlement, in The Political Economy of International Trade Law: Essays in Honor of Robert E. Hudec 457, 477 (Daniel L.M. Kennedy \& James Southwick eds., 2002).

56. Id. at 461.

57. Id. at 460 .

58. Id. at 467.

59. Judith Hippler Bello, Editorial Comment, The WTO Dispute Settlement Understanding: Less is More, 90 A m. J. INT'L L. 416, 416-17 (1996).

60. Id. at 417.

61. DSU, supra note 36.

62. Kym Anderson, Peculiarities of Retaliation in WTO Dispute Settlement, 1 World Trade Rev. 123,124 (2002). 
expires to determine mutually acceptable compensation by the loser, meaning the lifting of another trade barrier. If a satisfactory amount of compensation cannot be agreed upon, the winning party can request permission within twenty days of the reasonable time's expiry to take countermeasures against the losing party in the form of suspending other concessions previously made. However, should the respondent disagree with the amount of retaliation proposed by the prevailing party, the matter is sent to an arbitrator for a decision within sixty days. The decision of the arbitrator is then final. DSU compliance procedures, therefore, require agreement by both parties at multiple stages, ${ }^{63}$ suggesting far less obligation in the rules than purported.

A recent case that demonstrates the lack of obligation in the system is the Byrd Amendment case. ${ }^{64}$ The issue at hand-antidumping-is a politically charged one, important to domestic import-competing producers and the Members of Congress who support them. As a result, despite the ruling affirmed by the Appellate Body, subsequent EU and Japanese countermeasures, and even calls from the Bush Administration for its repeal, Congress refused to take action. It finally did repeal the law, but its provisions lasted until October 1, 2007, and as long as the United States could withstand the countermeasures from the EU and Japan, the WTO had no recourse to hasten withdrawal of the Byrd Amendment.

Kym Anderson has pointed out another weakness in DSB compliance procedures_stalling. A state could potentially take the full "reasonable time" and then announce that it has reformed the original offending policy. However, the complainant may claim that the reform measure is insufficient to bring the policy back into WTO consistency. In this case, the matter is again referred to a panel, which must report within 90 days on the matter. If the respondent is unsatisfied with that ruling, the measure goes to the Appellate Body for forty-five days. After that, the cycle could be repeated, leading to an "endless loop of litigation." ${ }^{* 5}$ As Marc Busch and Eric Reinhardt state, "The bottom line is that the WTO adjudication system is as much about 'defendants' rights' as it is about removing violations of established trade law."

Thus, WTO procedures afford Members methods by which they can tie up disputes in court while the home industry is being protected. Moreover, even when cases are resolved and countermeasures are imposed, a Member can choose

63. Id. at $124-25$.

64. See Panel Report, United States—Continued Dumping and Subsidy Offset Act, WT/DS234/R (Sept. 16, 2002).

65. Anderson, supra note 62, at 125.

66. Busch \& Reinhardt, supra note 55 , at 478. 
to simply endure those countermeasures to placate a certain domestic group. Or, better yet, impose its political will on a weaker state: "In the case ... where a weaker Member is faced with noncompliance by a disproportionately stronger member, the reactivation of power politics - which are at play in negotiations on compensation and the possible imposition of countermeasures-may make com-

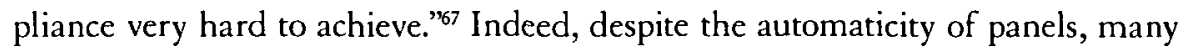
cases are stuck on noncompliance: “[ $t$ ]he 'legalization' of disputes under the WTO stops ... where noncompliance starts." ${ }^{\text {W8 }}$

In fact, in the opinion of U.S. interest groups-contrary to what is hypothesized in the literature- the WTO judicial system is not binding enough. In response to notices placed in the Federal Register by the Office of the United States Trade Representative (USTR) calling for public comments on the functioning of the WTO, "the comments expressed support for streamlining the dispute settlement and implementation processes and ensuring greater compliance with WTO rulings." ${ }^{\prime \prime 9}$ The domestic groups that filed these reports came from, among others, "numerous companies, trade associations, public interest groups, and other nongovernmental organizations." ${ }^{\text {" }}$ These comments suggest that, in addition to the flexibility the system affords, increased obligation is not a threat to U.S. domestic interest group support.

\section{Is Increased Precision in Danger of Undermining Domestic Political Support for the WTO?}

The danger that increased precision of trade rules poses to the WTO is allegedly one of better information. If rules are precise, then groups are more aware of whether the auspices of the WTO and other trade negotiations affect their interests-i.e., the regime becomes more transparent. As a result, interest groups are better able to conceptualize the costs and benefits of political mobilization. Increased mobilization, in turn, may translate into opposition to future WTO agreements because "the ability of leaders to sign an accord will depend on the groups mobilized for or against an accord." ${ }^{\text {11 }}$ Additionally, the increase in political mobilization is likely to be antitrade and anti-WTO in ideology because export groups are already

67. Joost Pauwelyn, Commentary, Enforcement and Countermeasures in the WTO: Rules are Rules-Toward a More Collective Approach, 94 AM. J. Int'L L. 335, 338 (2000).

68. Id.

69. Report to Congress, supra note 37 , at 11, n.6.

70. Id. at 10, n.6.

71. Goldstein \& Martin, supra note 6 , at 605. 
fully mobilized. Moreover, because "actors tend to react more strongly to losses than gains," "2 one could expect that antitrade groups will likely have an advantage on the political battlefield. However, the evidence suggests that increased precision of the rules has unlikely eroded U.S. domestic support for the WTO. First, the 26,000 pages of text in the URA may be highly precise, but its very precision also makes it virtually inaccessible to anyone not well-versed in trade law. Secondly, one would be hard pressed to argue that, as a result of the URA's highly precise rules, importcompeting industries suddenly realized that international trade could be detrimental to their interests. In actuality, it is not how precise or detailed the rules are, but the issues they concern. Import-competitors have almost always opposed international trade, no matter how precisely rules are written.

Goldstein and Martin, proponents of the precision theory, have offered data to support their contention: "One simple metric capturing the continued involvement of pro-protection groups in the United States is the number of bills entered in Congress pertaining to imports." ${ }^{\text {/3 }}$ Goldstein and Martin's figures are as follows:

- 1973-81:2,200 bills

- 1982-90: 2,300 bills

- 1991-98: 1,600 bills ${ }^{74}$

This does show continued involvement of pro-protection groups, but if anything, it demonstrates decreased involvement. Measuring the total number of import-competing groups opposed to the WTO would be difficult, but even if the number has increased, which it most likely has, the influence of import-competitors is nothing new. The groups that truly hold power in the formation of U.S. trade policy have not had any epiphanies as a result of increased rule precision. There may be increased opposition to the international trade regime as a result of legalization, but it is most likely a result of delegation, which is discussed later in the paper.

Moreover, even if precision has led to more transparency, and more transparency, in turn, has led to an increase in political opposition against trade liberalization and the WTO, closing to the public WTO doors that have already been cracked open would be a difficult task, and attempting to do so could prove fatal for the regime. The evidence supports such a notion: in response to the Federal Register notices mentioned above, "those who commented on transparency urged that the

72. Id. at 608 .

73. Id. at $610, \mathrm{n} .12$.

74. Id. 
United States seek greater transparency at the WTO, including more timely access to DSB documents, expanded access to DSB proceedings, and public participation in proceedings. ${ }^{75}$ This suggests that the only way to maintain domestic political support for the WTO is to increase legalization (i.e., become more transparent).

Finally, even if my contentions are incorrect, and increased precision has caused increased antitrade mobilization, the situation is still far from grim. Most of the American public still knows very little about the WTO: "[T] he WTO appears to have little political salience in the United States beyond the traditional sovereignty-obsessed nationalism of the far right, and the more recent, though equally paranoid, concerns of the NGO left." ${ }^{\text {"76 }}$ In blunter terminology: "For most Americans, the WTO is best known for its work on astonishingly minor issues such as bananas." ${ }^{77}$

\section{Is Increased Delegation in Danger of Undermining Domestic Political Support for the WTO?}

Delegation within the context of the WTO means delegation of the authority to panels and the Appellate Body to resolve trade disputes. Judging by the number of cases brought, increased delegation appears to be a success. However, the United States has voiced concern over what it describes as "judicial activism" by panelists and Appellate Body members. Judicial activism within the context of the WTO means that WTO judges are interpreting in or out responsibilities not supported by the WTO text. The threat to WTO legitimacy is a loss of confidence in the ability of panelists and Appellate Body members to correctly (in the view of the United States) interpret WTO law and adjudicate trade disputes competently.

The U.S. argument against judicial activism primarily rests on Article 3.2 of the Dispute Settlement Understanding (DSU), and Article 17.6 of the Antidumping Agreement. Article 3.2 of the DSU states that the DSB "cannot add to or diminish the rights and obligations provided in the covered agreements." ${ }^{78}$ Article 17.6 of the Antidumping Agreement states, with respect to investigations of domestic import agencies, "if the establishment of the facts was proper and the evaluation was unbiased and objective, even though the panel might have reached a

75. Report to Congress, supra note 37, at 11, n.6.

76. Noland, supra note 19, at 24.

77. Id.

78. DSU, supra note 36 , at art. 3.2 . 
different conclusion, the evaluation shall not be overturned." ${ }^{79}$ Moreover, if the panel finds that "the Agreement admits of more than one permissible interpretation, the panel shall find the authorities' measure to be in conformity with the Agreement if it rests upon one of those more permissible interpretations." ${ }^{\text {" } 0}$

One case in which the DSB purportedly extended beyond its delegated authority to increase responsibilities of Members was US-Hot Rolled Steel. ${ }^{81}$ The ruling turned on an interpretation of Article 3.5 of the Anti-Dumping Agreement, with the particular clause at issue being direction to domestic import authorities to "examine any known factors other than the dumped imports which at the same time are injuring the domestic industry." ${ }^{\prime 2}$ This means that if states wish to apply anti-dumping laws to a foreign government, they must ensure that it is the imports that are causing the injury, and not other factors. The Anti-Dumping Agreement further provides that the prosecuting state demonstrate that the "causal link" between imports and injury is unbroken. The panel found that the United States had satisfactorily performed this duty.

The Appellate Body reversed the decision, reading Article 3.5 as requiring an affirmative duty of "separating and distinguishing the injurious effects of the other factors from injurious effects of the dumped imports. ${ }^{.83}$ This reasoning, according to the United States, violates the standard of deference in Art. 17.6, and adds to the obligations of a Members in violation of DSU Art. 3.5. This, the United States contends, is judicial activism.

Another decision accused of adding extra-textual responsibilities to Members is the Byrd Amendment case. Here, the United States sought to encourage antidumping cases by appropriating the funds from winning cases to the businesses that brought the cases to the attention of the government. At issue was Article 18.1 of the Anti-Dumping Agreement, which states that "[n]o specific action against dumping of exports from another Member can be taken except in accordance with the provisions of GATT 1994." ${ }^{\prime 4}$ The decision turned on interpretation of

79. Agreement on Implementation of Article VI of the General Agreement on Tariffs and Trade 1994, art. 17.6(i), 33 I.L.M. 1125 (1994) [hereinafter Anti-Dumping Agreement].

80. Id. at art. 17.6(ii). One author has suggested that, although there exists no authoritative statement confirming as much, U.S. trade negotiators had the famous, deferential administrative law "Chevron standard" in mind. Daniel K. Tarullo, The Hidden Costs of International Dispute Settlement: WTO Review of Domestic Anti-Dumping Decisions, 34 Law \& PoL'y Int'L Bus. 109, $116-17$ (2002).

81. See Appellate Body Report, U.S.-Anti-Dumping Measures on Certain Hot-Rolled Steel Products from Japan, WT/DS/84/AB/R (July 24, 2001).

82. Anti-Dumping Agreement, supra note 79, at art. 3.5.

83. Cunningham \& Cribb, supra note 46 , at $158-59$.

84. Anti-Dumping Agreement, supra note 79, at art. 18.1 . 
the word "against," with the United States arguing that, while placing antidumping duties on imports may be an act "against" another Member, channeling antidumping revenues to producers is not. ${ }^{85}$ The panel disagreed, ruling that "against" meant having an "adverse bearing" on dumping, and because the Byrd Amendment 1) distorts competition between dumped and domestic products; and 2) offers payment as an incentive to bring suits, ${ }^{86}$ it is WTO illegal. The words of Senator Byrd himself confirm that there is a controversy over how much power should be delegated to the WTO DSB: "The WTO has decided that it--and not the U.S. Congress-has the authority to determine how American tax dollars are spent. This ruling flies in the face of the authority of Congress. ${ }^{.87}$

Finally, despite this paper's focus on the United States, it bears mentioning here that the United States is not the only country that has accused the DSB of judicial activism. In the Argentina-Footwear case, ${ }^{88}$ the Appellate Body purportedly tightened the use of safeguards without basis in WTO text. It reasoned that safeguards were only legal if the increase in imports harming the domestic sector were "recent enough, sudden enough, sharp enough, and significant enough. ${ }^{\circ 9}$ Negotiators did not include these words in the original agreement, and so Argentina questioned why such responsibilities were added.

Of course, not all WTO legal commentators agree that the DSB has been judicially active. James Durling has noted that "Panels and the Appellate Body have been deferential, but only when the particular decision deserved deference,"90 and notes, common-sensically, "One would have to doubt a WTO dispute settlement system that always found administering authorities to be correct." ${ }^{\text {"9l }}$ Ultimately, whether the DSB is justified in its interpretation of cases is outside the scope of this paper. The issue at hand is the U.S. governments' and their citizens' perception of the competency of the DSB. On this matter, the evidence suggests that judicial activism is indeed a perceived threat.

Both Congress and the Department of Commerce have expressed concern

85. John Greenwald, WTO Dispute Settlement: An Exercise on Trade Law Legislation?, 6 J. INT'L Econ. L. 113, 120-21 (2003).

86. Id. at 121.

87. Id. at 122 .

88. Appellate Body Report, Argentina-Safeguard Measures on Imports of Footwear, WT/DS121/ AB/R (Jan. 12, 2000).

89. Greenwald, supra note 85 , at 116 .

90. James P. Durling, Deference, But Only When Due: WTO Review of Anti-Dumping Measures, 6 J. Int'L Econ. Law 125, 125 (2003).

91. Id. at 126. 
over WTO panel and Appellate Body interpretations. In response to a string of losses before the DSB, Congress requested the Commerce Department to submit a report addressing whether the DSB had added to the obligations and/or diminished the rights of the United States. In that report, the Department of Commerce summarized the crucial issues:

The United States does not agree with the approach that the WTO panels and the Appellate Body have sometimes taken in disputes, and is concerned about the potential systemic implications. In particular, the executive branch views with concern the manner in which WTO panels and the Appellate Body have applied the applicable standards of review in disputes involving U.S. trade remedy and safeguard matters, and instances in which they have found obligations and restrictions on WTO Members concerning trade remedies and safeguards that are not supported by texts of the WTO agreements. When the agreements were signed, Members ... struck a very careful balance of commitments that provided them with certain benefits and costs. These benefits and costs formed the foundation upon which Members ratified the agreements and sustained Members' support for the agreements over the years. If the perception develops that the WTO panels and the Appellate Body are substituting their own policy judgment for a negotiated balance of rights and obligations, then it will be difficult to maintain the support and confidence of Members and the public in the value of future negotiations. ${ }^{92}$

As is mentioned above, the fact that these rulings have limited U.S. use of anti-dumping and countervailing duty (AD/CVD) laws has made judicial activism an especially contentious issue. A central tenet of U.S. trade policy is one of "fairness," and AD/CVD laws are a principal method by which the United States promotes a "level playing field." ${ }^{\prime 4}$ While most neoliberal economists may disagree with this reasoning, U.S. lawmakers, whose jobs depend on votes, find it difficult to explain the diffuse benefits of free trade over the simple rhetoric of

92. Report to Congress, supra note 37 , at 7.

93. Judith Goldstein, Ideas, Institutions, and American Trade Policy, 42 INT'L Org. 179, 181 (1998).

94. See generally N. Gregory Mankiw \& Phillip L. Swagel, Antidumping: The Third Rail of Trade Policy, Foreign Aff. Jul.-Aug. 2005, at 107. 
"fairness." As N. Gregory Mankiw and Phillip Swagel explain: "Advocates of antidumping measures claim that they guarantee that international trade is competitive and fair. And who, they ask, could be against fairness?"

This message of fairness, furthermore, is being delivered by an economically sensitive and politically volatile sector: labor-intensive producers. The producers face increasing elasticity in the demand for their products due to the rise of similar imports from developing countries. Labor-intensive producers also "provoke the greatest American political disquiet."96 These two characteristics, taken in tandem, make for an extremely defensive political posture on "fair" trade.

Reform of American trade remedy laws, moreover, is, in the opinion of Mankiw and Swagel, politically unthinkable-so much so that they labeled trade remedy laws the "third rail" of U.S. trade politics. Mankiw and Swagel conclude that "outright repeal of U.S. antidumping laws. . is politically unfeasible,"97 and caution against the ramifications of further U.S. losses in Geneva: "Each loss is a blow to public and Congressional support for an institution that is a powerful force for improving global economic conditions and promoting international cooperating." ${ }^{98}$

Indeed, public opinion suggests that domestic interest groups are concerned about judicial activism, especially with respect to trade remedies. Interest groups have stated: "WTO panels and the Appellate Body have not properly applied the standards of review in trade remedy cases, resulting in DSB recommendations that lack a textual basis in WTO agreements and impermissibly add to the obligations or diminish the rights negotiated in WTO agreements. ${ }^{\text {'p9 }}$ Furthermore, these groups cautioned against weakening the Antidumping Agreement and the Agreement on Subsidies and Countervailing Measures throughout the Doha Development Agenda. This sentiment is far from pervasive, though, because "[o]ther powerful U.S. interest groups care little about these cases" and, furthermore, with respect to U.S. implementation, "the required changes in US law [as a result of losses] have generally been marginal." 100 Still, there is reason for concern: "A continuous stream of trade remedy cases before the Appellate Body raising essentially the same issues and reaching the same results will lead to cynicism about the effectiveness of WTO dispute settlement." ${ }^{\text {101 }}$

95. Id. at 107-08.

96. Sen, supra note 11 , at 133.

97. Mankiw \& Swagel, supra note 94 , at 117.

98. Id. at 119.

99. Report to Congress, supra note 37 , at 11.

100. Steinberg, supra note 6, at 270.

101. Donald McRae, What is the Future of WTO Dispute Settlement?, 7 J. INT'L Econ. L. 3, 16 (2004). 
Nevertheless, the public opinion evidence demonstrates that WTO judicial activism, especially with respect to antidumping and countervailing duty laws, is indeed an issue of concern for the U.S. Executive Branch, the U.S. Congress, and the constituents they represent. But how concerned should other WTO Members really be? Will judicial activism completely undermine U.S. domestic political support in the near future, or is it simply an "irritant"102 to the system? Although "political science lacks cognitive models that are robust enough, and the complete information necessary, to make perfect predictions about the political consequences of WTO judicial decisions"103 the empirical, institutional, and historical evidence demonstrates that U.S. domestic political support for the WTO has not waned enough to seriously undermine the global trade regime.

One simple metric of U.S. support is its win-loss record. ${ }^{104}$ As of December 31,2003 , in dispositive reports with the U.S. as complainant, it was 85 percent successful, winning seventeen cases and losing three. As a respondent, it was 81 percent unsuccessful, losing twenty-two and winning five. The difference between these numbers, according to Steinberg, is "not statistically significant," and therefore, the DSB has not fundamentally altered the U.S. rights and obligations and remains within its political space. ${ }^{105}$

The Department of Commerce rejects the win-loss record model, though it, too, concludes that the United States has fared reasonably well in the WTO judicial system. The Commerce Department notes that each case contains a wide range of issues, so even if the United States loses on some issues, it wins on others. Win-loss records, the Department points out, do not mention cases that are resolved positively at the consultation stage, nor could they include a measure of the deterrent factor the DSB has on countries that contemplate enacting WTO-inconsistent measures. ${ }^{106}$ Finally, on many occasions, according to the Commerce Department, rulings adverse to the United States were nevertheless easy to implement. ${ }^{107}$

Additionally, despite the recent losses on AD/CVD measures, many U.S. producers have actually fared quite well with the DSB. These industries include manufacturers and exporters of autos and auto parts; agricultural producers, processors,

102. Id.

103. Steinberg, supra note 6 , at 267.

104. Id. at 268-69 (Examining this data is suggested by Steinberg. He contends that examining the U.S. and EU win-loss record provides insight into whether the DSB has fundamentally altered the rights and obligations of the major powers).

105. Id. at 270.

106. Report to Congress, supra note 37 , at 6.

107. Id. 
and exporters; intellectual property rights holders; beef producers; alcoholic beverage manufacturers; and magazine publishers, just to name a few. The domestic political costs of losses "have been offset by domestic political benefits from WTO dispute settlement outcomes that have favored U.S. export-orientation." fervor ever reached a point that the United States was truly contemplating WTO withdrawal, these industries could be expected to counter such a proposal.

The WTO judicial system also has institutional mechanisms by which it can buffer U.S. criticism. Powerful WTO Members such as the United States effectively have a veto over the selection of panel and Appellate Body judges. The DSB has also practiced "judicial economy" in some cases, preferring not to rule on politically sensitive matters. When such rulings are unavoidable, the DSB has gone out of its way to make compliance with the rulings easy. Finally, the DSB always acts in the shadow of reform, meaning that Members would change the DSB rules if judicial activism ever assumed too much delegated authority. ${ }^{109}$

Indeed, institutional reform of the system is more likely than complete U.S. withdrawal because the United States still supports the idea of a dispute settlement mechanism: "Because it is necessary to resolve differences that inevitably arise between parties to such a system, an effective dispute settlement mechanism is an essential component of the WTO regime." 110 The United States also believes that, on balance, the system serves its interests: "The United States recognizes that an effective dispute settlement system advantages the Unites States not only through the ability to secure the benefits negotiated under the agreements, but also by encouraging the rule of law among nations."'11

The history surrounding the original development of a global trade regime also demonstrates that U.S. domestic political support is unlikely to wane in the near future. The original idea for a "world trade organization" was raised in the years immediately following World War II in the form of the International Trade Organization (ITO). The ITO never came into existence because it was rejected by domestic interests in the United States vis-à-vis Congress. These domestic interests made up a coalition of, on the one hand, the traditional protectionist groups such as agriculture, who would have opposed any new free trade agreement, and on the other hand, businesses who were typically free traders. The latter opposed the ITO because it was not liberal or multilateral enough: "In their eyes the ITO

108. Steinberg, supra note 6 , at 270.

109. Id. at 269 .

110. Report to Congress, supra note 37 , at 1 .

111. Id. at 2. 
represented a step away from trade liberalization."12 With both of these groups firmly opposed to the agreement, Congress naturally refused to ratify it. More formally, "the legislature ... may depend on the endorsements of informed domestic groups in deciding whether to ratify. "If none of the key groups endorses an agreement, ratification should always fail.",13

It is this danger-loss of support by both import competitors and traditional free traders-that will signal the end of U.S. domestic support. Traditional protectionists will always be wary of the WTO, but a loss of confidence among multilateralists is the true danger. If the multilateralists, such as export-oriented businesses, come to believe that the text of negotiated agreements is meaningless, that it is inherently biased against the United States, or that the WTO is a "broken system" beyond reform, they will withdraw their support. Currently, the success of export-oriented businesses vis-à-vis the WTO is an "excuse" for continued U.S. support of the multilateral trade order. As was the case in the time of the ITO, Congress looks to business groups as "endorsers" of the WTO. ${ }^{114}$ But again, if these businesses and the multilateralists start sending the signal that the WTO is not in the U.S.'s interest, a serious crisis of confidence may ensue.

\section{Conclusion: Future Prospects for the Global Trade Regime}

Has the WTO reached, in the words of Gautam Sen, "an inescapably symbolic and politically significant turning point?" $115 \mathrm{Or}$, are the persistent U.S. grumblings towards the WTO merely an expected outgrowth of the interaction between traditional protectionists and the legalization of free trade? This paper has argued that it is more likely the latter, contending that U.S. domestic political support has not been undermined as a result of WTO legalization, contrary to some claims made in the existing literature. One caveat, however, has been flagged as a potential long-term threat to U.S. domestic political support-judicial activism of the DSB. Should judicial activism persist to the point that multilateralists think the DSB disregards negotiated text, a crisis of confidence might well ensue, and, as it did with the ITO, the United States would reject the global trade regime.

As an economic leader in the WTO, U.S. withdrawal from the regime would

112. Helen Milner, Interests, Institutions, and Information: Domestic Politics and International Relations 147 (1997).

113. Id. at 148 .

114. Id.

115. Sen, supra note 11 , at 135. 
likely prove catastrophic. In 2006 , the U.S. exported over $\$ 1$ trillion worth of merchandise worldwide, ${ }^{116}$ and imported $\$ 1.85$ trillion. ${ }^{117}$ Without the low tariff arrangements of the WTO, global trade with the United States would be severely hampered. This, in turn, would likely spark a worldwide recession and set globalization back decades-not just economically but diplomatically as well because, as Baron de Montesquieu wrote in 1748, "Peace is the natural effect of trade. Two nations who differ with each other become reciprocally dependent; for if one has an interest in buying, the other has an interest in selling: and thus their union is founded on mutual necessities."

If the WTO did manage to continue without U.S. membership, it would nevertheless miss American political leadership against the trend of regional trading agreements. More than any other country, the United States has pushed the multilateral trade regime, especially as Europe has become more and more integrated. ${ }^{119}$ Without the United States, it is plausible that Members would be content to let the global trade regime stagnate and would likely retreat into regional trading blocs. ${ }^{120}$ Even now with the United States as a Member, the Doha Round has failed to yield much progress, and some have even declared the talks essentially dead. ${ }^{121}$

Indeed, the WTO is left precariously teetering on the balance of many planes. States opted into the WTO and formalized its rules to further prevent trading partners from cheating, but legalizing trade rules too tightly constrains states in breaching their commitments when dictated by economic circumstances. WTO Members delegated responsibility to rule on disputes concerning rights and responsibilities among states, but not to add or diminish either in the process. Finally, in democracies such as the United States, domestic political support for the WTO is essential for continued membership, and the Uruguay Round repre-

116. Department of Commerce Trade Statistics on Exports, available at http://tse.export.gov/ MapFrameset.aspx ? MapPage $=$ NTDMapDisplay.aspx $\&$ UniqueURL $=0$ rf 3 fjas 12 fiy w 45 plre h155-2007-7-14-16-25-41 (last visited Jan. 16, 2008).

117. Department of Commerce Trade Statistics on Imports, available at http://tse.export.gov/ MapFrameset.aspx ? MapPage $=$ NTDMapDisplay.aspx \& UniqueURL $=0 \mathrm{rf} 3$ fjas $12 \mathrm{fiy} \mathrm{w} 45 \mathrm{pl}$ re h155-2007-7-14-16-30-32 (last visited Jan. 16, 2008).

118. Baron de Montesquieu, The Sirit of the Laws 316 (Thomas Nugent trans., Harper Publishing Co. 1966) (1748).

119. Richard Feinberg, The Political Economy of United States' Free Trade Agreements, 26 WorLD Econ. 1019 (2003).

120. To be sure, the U.S. has also vigorously pursued bilateral and regional trade agreements. However, this has been done both as leverage against the Europeans and insurance in case multilateral trade talks fail. See id. at 1019-20.

121. See In the Twilight of Doha, The Economist, Jul. 29, 2006. 
sented a careful balance between both liberalism and protectionism, and legalism and diplomacy. If the scales are tipped too far in any of these directions, serious challenges to U.S. membership in the WTO, the WTO's status as a global institution, and, by extension, flows of international trade, will emerge. Presently, however, the evidence suggests that this balance has not been upset. 